\title{
Lektorok, 2017
}

\section{Reviewers, 2017}

2017-ben 81 lektorral dolgoztunk együtt, akik szakértelmükkel segítették a szerkesztőséget és a szerzőket abban, hogy a Tér és Társadalomban színvonalas tanulmányok jelenhessenek meg. Ezúton is köszönjük munkájukat! 2017-ben lektoraink voltak:

$\begin{array}{lll}\text { Bajmócy Zoltán } & \text { Hideg Éva } & \text { Németh Krisztina } \\ \text { Balogh Péter } & \text { Illés Anikó } & \text { Pálné Kovács Ilona } \\ \text { Barta Györgyi } & \text { Imre Gabriella } & \text { Pankucsi Márta } \\ \text { Beluszky Pál } & \text { Ivanics Zsófia } & \text { Pénzes János } \\ \text { Borbély Sándor } & \text { Izsák Éva } & \text { Pósfai Zsuzsanna } \\ \text { Boros Lajos } & \text { Jankó Ferenc } & \text { Rácz Katalin } \\ \text { Czirfusz Márton } & \text { Jaschitz Mátyás } & \text { Rátz Tamara } \\ \text { Csatári Bálint } & \text { Jóna László } & \text { Rechnitzer János } \\ \text { Csizmadia Zoltán } & \text { Kerekes Sándor } & \text { Sági Mirjam } \\ \text { Deák András György } & \text { Keresztély Krisztina } & \text { Ságvári Bence } \\ \text { Dusek Tamás } & \text { Koós Bálint } & \text { Sik Endre } \\ \text { Elekes Tibor } & \text { Koszorú Lajos } & \text { Sikos T. Tamás } \\ \text { Erőss Ágnes } & \text { Kovács Nóra } & \text { Simonovits András } \\ \text { Fábián Attila } & \text { Kovács Zoltán } & \text { Szalkai Gábor } \\ \text { Farkas Jenő Zsolt } & \text { Kovai Cecília } & \text { Szunomár Ágnes } \\ \text { Fejős Zoltán } & \text { Kozma Tamás } & \text { Tagai Gergely } \\ \text { Fertő Imre } & \text { Kriszt Éva } & \text { Takács István } \\ \text { Fleischer Tamás } & \text { Kukely György } & \text { TakácsnéGyörgy Katalin } \\ \text { Forray Katalin } & \text { Lendvay Márton } & \text { Timár Judit } \\ \text { G. Fekete Éva } & \text { Lux Gábor } & \text { Tóth Géza } \\ \text { Gál Zoltán } & \text { Mezei Cecília } & \text { Töröcsik Mária } \\ \text { Gerőcs Tamás } & \text { Mezei Katalin } & \text { Túry Gábor } \\ \text { Győri Róbert } & \text { Mihály Melinda } & \text { Vadas András } \\ \text { Hajdú Zoltán } & \text { Molnár Ernő } & \text { Váradi Monika Mária } \\ \text { Hajdu-Smahó Melinda } & \text { Nagy Erika } & \text { Varjú Viktor } \\ \text { Hamar Anna } & \text { Nagy Gábor } & \text { Virág Tünde } \\ \text { Hárs Ágnes } & \text { Nagy Zoltán } & \text { Zentai Violetta } \\ & & \end{array}$

